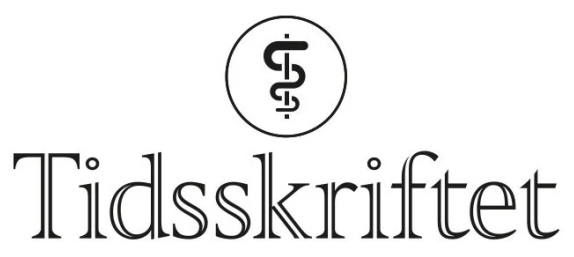

DEN NORSKE LEGEFORENING

\title{
Legeutdanning under en pandemi
}

\section{LEDER}

\section{METTE BREKKE}

Allmennmedisinsk forskningsenhet

Universitetet i Oslo

Hun har bidratt med studiedesign, revisjon av manus og godkjenning av innsendte manusversjon. Mette Brekke er professor.

Forfatteren har fylt ut ICMJE-skjemaet og oppgir ingen interessekonflikter.

\section{CATHRINE EBBING}

Cathrine Ebbing, associate professor at the Department of Clinical Science, University of Bergen. The author has completed the ICMJE form and declares no conflicts of interest.

\section{TORBEN WISBORG}

Torben Wisborg er spesialist i anestesiologi, professor, overlege og forskningsleder ved Nasjonal kompetansetjeneste for traumatologi.

Forfatteren har fylt ut ICMJE-skjemaet og oppgir ingen interessekonflikter.

\section{Covid-19-pandemien har gjort legeutdanningen til et ensomt og nettbasert studium. Hvordan kan vi sikre at medisinstudentene likevel blir fullverdige leger?}

I disse dager starter nye studentkull på medisinstudiet her hjemme og ved utenlandske studiesteder. Vi har lagt bak oss et vårsemester preget av pandemiens «tredje bølge», med høye smittetall, nedstenging og venting på vaksiner. Dette ser heldigvis ut til å kunne være over, men store spørsmål gjenstår: Hvordan vil høsten bli? Vil samfunnet - og dermed universitetene - nærme seg en normal situasjon? Vil de nye studentene igjen kunne møte lærere i et stappfullt auditorium? Vil studentene bli kjent med hverandre i kantina og på studentpuben? Vi håper det, men foreløpig vet vi lite.

Som lærere har vi tilpasset oss en stadig skiftende virkelighet og har forsøkt å finne løsninger for å holde en best mulig legeutdanning i gang under pandemien. Den digitale læringskurven har vært bratt, og noen av oss har faktisk begynt å trives med å undervise på Zoom. Vi har gjennomført praksisundervisning både i og utenfor sykehus, men vi kan ikke nekte for at den har blitt amputert. Ved Universitetet i Oslo har for eksempel «tidlig pasientkontakt» hos fastlege måttet skje delvis digitalt, og praksis i sykehjem ble avlyst for to av kullene. I tillegg har sykehusene forståelig nok vært restriktive med å slippe til studentene på grunn av smitterisikoen (1). 
Studentene forteller at de har lært mindre de tre foregående semestrene enn tidligere. Dette gjelder særlig praktiske ferdigheter, som de i liten grad har fått øve på. Dessuten er det slitsomt å sitte foran en skjerm dagen lang. Noen blir ekstra passive fordi de sitter på lesesal eller i andre fellesområder der de ikke kan snakke fritt. Det er vanskelig å logge av både skjermen og hodet om kvelden og i helgen, og skillet mellom arbeid og fritid blir visket ut. Og ikke minst: Medisinstudiet er blitt et ensomt studium. Dette er særlig merkbart for de ferske studentene som ikke har rukket å etablere et nettverk med kollokviegrupper og venner som de kan jobbe sammen med og måle seg mot. Det er lett å bli motløs og lei (2). Gitt mindre interaksjon med lærere og medstudenter fra eget og høyere kull er studentene redde for at de har uoppdagede kunnskapshull.

Hvordan skal vi sikre at vi fortsatt utdanner kvalifiserte leger, at "pandemikullene» ikke blir dårligere enn de andre? Vet vi at vi vurderer studentenes kunnskaper på en riktig og rettferdig måte? Og er det mulig å hjelpe studentene til å finne mening, trivsel og trygghet i studiehverdagen? Ved noen studiesteder tilbyr man å hjelpe studentene med å starte opp kollokviegrupper. Flere universiteter har etablert smågrupper med en fast kontaktlærer som følger sin gruppe gjennom hele semesteret. Dette bidrar til å skape kontakt, til økt samarbeid og støtte.

«Kanskje bør det i større grad tas i bruk mentorordninger som gjør det mulig å identifisere studenter i risikosonen?»

Kanskje bør det i større grad tas i bruk mentorordninger som gjør det mulig å identifisere studenter i risikosonen (3)? Nye eksamensformer med digitale hjemmeeksamener og digitale kliniske eksamener uten pasient er krevende for både eksaminator og student. Eksamenskommisjonene har gjort en stor jobb for å få til dette på en transparent og rettferdig måte, og vi mener vi har lykkes. Det at vi har prøvd ut nye eksamensformer kan gi oss mer å velge mellom også etter pandemien. Selv om undervisning med studenter og lærer til stede er å foretrekke, er nok noe av den digitale undervisningen kommet for å bli.

Alle anstrengelser til tross: Pandemien påvirker medisinstudiet, og studentene får med seg erfaringene i bagasjen videre, både på godt og vondt. Digital undervisning har nok ført til større fleksibilitet i hverdagen og kan ha gjort det lettere å kombinere studiet med familie og jobb. Mange har jobbet nettopp med smittesporing, prøvetaking o.l. Studentene har opplevd - så å si på kroppen - hvor viktig et velfungerende helsevesen er, ikke bare innen intensivmedisin, men i like stor grad forebygging og smittevern. De har sett hvor avgjørende det er at helsetjenesten har befolkningens tillit. For klinikere og lærere gjelder det å være oppmerksom på at de neste kullene av ferdige leger kan ha fått mindre praktisk opplæring og dermed har større behov for prosedyretrening når de kommer som LIS1-lege i allmennpraksis og på sykehus. De vil bli like flinke leger på sikt, men vi må forberede oss på å bruke lengre tid i starten på å sikre at de kan det som tidligere studenter fikk bedre anledning til å lære i studietiden.

Uansett - velkommen skal alle nye studenter være! Vi skal gjøre vårt beste for å lære dere det vi kan og for å vurdere dere rettferdig. Og vi skal gi dere tid til å mestre de praktiske prosedyrene når dere forhåpentligvis snart får anledning til å prøve dere klinisk. 
1. Brown A, Kassam A, Paget M et al. Exploring the global impact of the COVID-19 pandemic on medical education: an international cross-sectional study of medical learners. Can Med Educ J 2021; 12: 28-43. [PubMed]

2. ElHawary H, Salimi A, Barone N et al. The effect of COVID-19 on medical students' education and wellbeing: a cross-sectional survey. Can Med Educ J 2021; 12: 92-9. [PubMed]

3. Skjevik EP, Boudreau JD, Ringberg U et al. Group mentorship for undergraduate medical studentsa systematic review. Perspect Med Educ 2020; 9: 272-80. [PubMed][CrossRef]

Publisert: 16. august 2021. Tidsskr Nor Legeforen. DOI: 10.4045/tidsskr.21.0548

(C) Tidsskrift for Den norske legeforening 2023. Lastet ned fra tidsskriftet.no 26. april 2023. 